\title{
МІСЦЕВІ БЮДЖЕТИ В УМОВАХ ДЕЦЕНТРАЛІЗАЦІї: ТЕОРЕТИЧНІ АСПЕКТИ
}

\author{
Плукар Любов Андріївна \\ кандидат економічних наук , доцент \\ ПВНЗ "Європейський університет" (м. Львів, Україна), \\ ORCID ID: 0000-0001-9914-7552 \\ Lyuba.plukar@gmail.com
}

Розглянуто періодизацію розвитку системи місцевих бюджетів в умовах незалежності України, а саме 4 періоди: 1990-2000 2001-2009, 2010-2013, 2014 і по сьогоднішній день, зазначено основні нормативно-правові акти, які приймалися в даний період та мали найбільший вплив на розвиток бюджетної системи, а також основні зміни, які відбулись в даний час. Досліджено підходи українських вчених до трактування поняття «місцеві бюджети». Розглянуто структуру бюджетної системи та місце в ній місцевих бюджетів. Визначено нормативно-правові акти, які мали вплив на формування бюджетноподаткової децентралізації. Зазначено основні зміни процесу формування та виконання місцевих бюджетів в період децентралізації бюджетних ресурсів та видаткових повноважень органів місцевого самоврядування, а саме: розпочато реформу місцевого самоврядування та територіальної організації влади; запущено процес формування достатніх фрінансово-організаційних умов розвитку територіальних громад; дозволене самостійне формування місцевих бюджетів незалежно від термінів прийняття державного бюджету; запровадження систему вирівнювання податкоспроможності територій; реформовано існуючі податки і збори.

Ключові слова: місцеві бюджети, місцеве самоврядування, адміністративно територіальна рефрорма, децентралізація

DOI: https://doi.org/10.32845/bsnau.2019.4.30

Постановка проблеми у загальному вигляді. Дослідження поняття «місцеві бюджети» напряму пов'язане із розвитком субнаціональних органів влади. Враховуючи, що розвиток місцевих бюджетів відбувався в історичному контексті, в залежності від розвитку державності та традицій управління, особливостей формування та укріплення місцевого самоврядування, доцільно розглянути питання періодизації становлення та розвитку системи для виявлення напрямку подальшого розвитку місцевих бюджетів, а також відмінностей між системою, яка сформувалася станом на сучасний період, та системою у різні періоди минулого.

Аналіз останніх досліджень та публікацій. Питаннями ролі та місця місцевих бюджетів у бюджетній системі займалося багато вітчизняних науковців, а саме: О. Василик, Н. Власюк, О. Кириленко, В. Кравченко, Т. Мединська, М. Мельник, О. Матвеєва, І. Опарін, А. Пелехатий, М. Ходорович та інші. Однак, і до сьогодні мало вивченими залишаються питання теоретичних основ місцевих бюджетів в умовах децентралізаційних процесів.

Формування цілей статті. Метою даного дослідження $€$ аналіз теоретичних аспектів розвитку місцевих бюджетів та дослідження наукових підходів до визначення поняття бюджетів як економічної категорії.

Методи дослідження. У дослідженні були використані такі методи, як систематизації та узагальнення - при аналізі нормативних документів та теоретичних джерел та

абстрактно-логічний метод - для визначення пріоритетних напрямів розвитку системи місцевих бюджетів.

Результати дослідження. Зважаючи на динамічність розвитку місцевих фінансів як елемента фінансової системи держави, доцільним є провести дослідження зміни та особливостей трактування поняття «місцеві бюджети».

Період існування незалежної Української держави 3 позиції періодизації розвитку системи місцевого самоврядування та місцевих бюджетів також доцільно поділити на окремі етапи (рис. 1.). Особливістю першого етапу розвитку місцевих бюджетів було формування бюджетної системи України на «фундаменті», закладеному у період функціонування адміністративно-командної економіки, а відтак перейняття «рис» та особливостей формування бюджетів Радянського Союзу.

Щодо другого та третього етапів, саме у цей період виникла мова про потребу забезпечення фінансової спроможності територіальних громад, проте системних кроків у цьому напрямі зроблено не було, окрім розширення переліку доходів місцевих бюджетів та встановлення порядку реалізації програмно-цільового методу бюджетування за рахунок внесення змін до Бюджетного кодексу у 2010 році.

Четвертий етап розвитку місцевих бюджетів триває і станом на сьогодні і передбачає рух у напрямі адміністративно-фінансової децентралізації, що буде розглянуто у наступних параграфрах. 


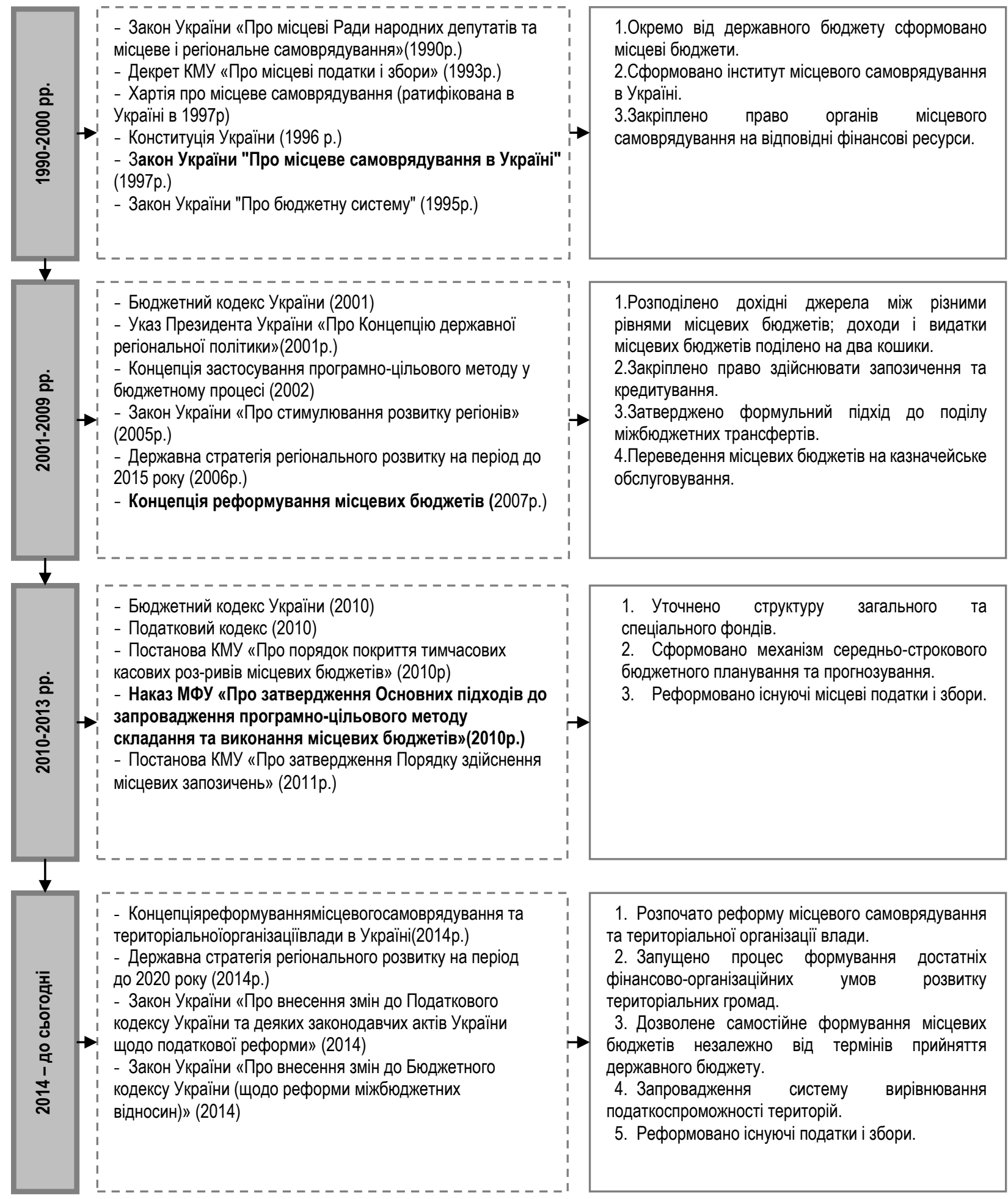

Рис. 1. Періодизація розвитку системи місцевих бюджетів в умовах незалежності України

Джерело: сформовано автором

Зважаючи на динамічність розвитку місцевих фрінансів як елемента фінансової системи держави, доцільним $€$ провести дослідження зміни та особливостей трактування поняття «місцеві бюджети».

Вперше визначив наукові засади фрункціонування місцевого самоврядування та необхідності забезпечення фінансової основи їх розвитку засновки теорії публічних фінансів Адам Сміт. Вагомий вклад у наукове обґрунтування місцевих бюджетів внесли А. Вагнер, К. Рау, Л. Штейн, Р. фон
Каусрман та інші. Серед російських вчених, дослідженням поняття займалися А. Марков, І. Янжул, М. Смірнов, І. Озеров, М. Курчинський. Проте дослідження цих вчених не торкалися безпосередньо розкриття суті та структури місцевих бюджетів; місцеві бюджети розглядалися радше в контексті матеріальних засобів, що перебувають у розпорядженні влади на місцевому рівні. Разом з тим, можна зазначити, що ретроспективний аналіз сутності та ролі місцевих бюджетів зі сторони їх трактування вченими дозволяє акцентувати увагу на 
діалектичному взаємозв'язку розвитку бюджетів та поступу системи державного управління.

Щодо вітчизняних науковців, можна зауважити різні підходи до трактування поняття «місцеві бюджети» (табл. 1.).

Більшість науковців (В. І. Кравченко, О. П. Кириленко, П. К. Бечко, О. В. Ролінський та інші) розглядають дану категорію у трьох аспектах: як нормативно-правововий акт, як план доходів та видатків, як економічну категорію. Натомість інші економісти (О. Матвєєва, М. А. Гапонюк, В.П. Яцюта) наполягають на дуальній сутності місцевих бюджетів, оскільки вони, по-перше, виступають складовою бюджетної системи держави, по-друге, є ключовим елементом місцевих фінансів та фундаментом розвитку місцевого самоврядування.

Підходи українських вчених до трактування поняття «місцеві бюджети»

Таблиця 1.

\begin{tabular}{|c|c|c|}
\hline Автор, рік & Рік & Трактування категорії \\
\hline 1 & 2 & 3 \\
\hline І.М. Ходорович [3] & 1977 & $\begin{array}{l}\text { Це сукупність економічних відносин, що забезпечують у плановому порядку фінансову базу } \\
\text { місцевих рад щодо розвитку й утримання головним чином галузей господарства, які } \\
\text { безпосередньо спеціалізуються на підвищенні добробуту населення. }\end{array}$ \\
\hline В.І. Кравченко [4] & 1999 & $\begin{array}{l}\text { По-перше, це правовий акт, згідно з яким виконавчі органи влади отримують легітимне право } \\
\text { на розпорядження певними фондами грошових ресурсів; по-друге, це план (кошторис) доходів } \\
\text { і видатків відповідного місцевого органу влади чи самоврядування; по-третє, це економічна } \\
\text { категорія, оскільки бюджет є закономірним атрибутом будь-якої самостійної територіальної } \\
\text { одиниці, наділеної відповідним правовим статусом. }\end{array}$ \\
\hline В.М. Опарін [5] & 1999 & $\begin{array}{l}\text { Це частина основного річного фінансового плану країни - державного бюджету, крім того, } \\
\text { місцеві бюджети утворюють централізований фонд грошових коштів місцевих Рад, котрим } \\
\text { вони розпоряджаються з метою здійснення заходів, які щорічно передбачаються планом } \\
\text { економічного і соціального розвитку. }\end{array}$ \\
\hline О. Д. Василик[6] & 2000 & $\begin{array}{l}\text { Виділено організаційний (місцеві бюджети є балансовими розрахунками доходів та витрат, які } \\
\text { мобілізуються та витрачаються на певній території) та категоріальний (місцеві бюджети є } \\
\text { системою фрінансових відносин, яка охоплює, по-перше, відносини між місцевими бюджетами } \\
\text { і господарськими структурами, які функціонують на певній території; по-друге, відносини між } \\
\text { бюджетами і населенням певної території, що складаються при мобілізації й витрачанні коштів } \\
\text { місцевих бюджетів; по-третє, відносини між місцевими бюджетами різних рівнів з приводу } \\
\text { перерозподілу фінансових ресурсів; по-четверте, відносини між державними та місцевими } \\
\text { бюджетами ) підходи до визначення місцевих бюджетів. }\end{array}$ \\
\hline О.П. Кириленко [7] & 2000 & $\begin{array}{l}\text { Місцеві бюджети є фінансовим планом розвитку певної території, в якому відображаються } \\
\text { найважливіші завдання місцевої влади та очікувані результати діяльності. } \\
\text { Акцентуючи увагу на розгляді місцевого бюджету як фінансового плану, автор наголошує і на } \\
\text { широкому діапазоні функцій бюджетних відносин місцевого рівня, а саме: макроекономічне } \\
\text { регулювання та забезпечення пропорційного розвитку території; забезпечення соціальних } \\
\text { видатків; підтримка і забезпечення життєдіяльності населення; функціонування як фінансова } \\
\text { основа місцевого самоврядування; реалізація регіональної політики та загальнодержавних } \\
\text { програм розвитку. }\end{array}$ \\
\hline $\begin{array}{l}\text { М. А. Гапонюк, В. П. } \\
\text { Яцюта та інші[8] }\end{array}$ & 2002 & $\begin{array}{l}\text { При розкритті сутності місцевих бюджетів слід виходити з того, що місцеві бюджети, з одного } \\
\text { боку, є складовою частиною бюджетної системи держави, а з іншого — складовою частиною } \\
\text { місцевих фінансів і віддзеркалюють певну систему економічних відносин. }\end{array}$ \\
\hline $\begin{array}{l}\text { І. Сазонець, Т.Гринько, } \\
\text { Г.Придатко [8] }\end{array}$ & 2006 & $\begin{array}{l}\text { Місцеві бюджети - фонди фінансових ресурсів для реалізації завдань і функцій, які } \\
\text { накладаються органами місцевого самоврядування. }\end{array}$ \\
\hline $\begin{array}{c}\text { П.К. Бечко, } \\
\text { О.В.Ролінсь-кий [8] }\end{array}$ & 2007 & $\begin{array}{l}\text { Місцеві бюджети як економічна категорія відображають грошові відносини, що виникають між } \\
\text { місцевими органами самоврядування та суб'єктами розподілу створеної вартості в процесі } \\
\text { формування територіальних грошових коштів, які використовуються для соціально- } \\
\text { економічного розвитку регіонів та поліпшення добробуту населення. }\end{array}$ \\
\hline О. Матвеєва [9] & 2010 & $\begin{array}{l}\text { Місцевий бюджет - це поліфункціональна система економічних відносин, які встановлюються } \\
\text { між урядом і громадянами у сфері створення, використання та ефективного розподілу ВВП в } \\
\text { грошовому еквіваленті з метою найбільш повного задоволення потреб місцевого населення. }\end{array}$ \\
\hline $\begin{array}{l}\text { Н.І.Власюк, } \\
\text { Т.В.Мединсь-ка, } \\
\text { М.І.Мельник [10] }\end{array}$ & 2011 & $\begin{array}{l}\text { Сукупність економічних (грошових) відносин, що виникають у зв'язку з утворенням і } \\
\text { використанням фондів грошових засобів місцевих органів влади у процесі перерозподілу } \\
\text { національного доходу } 3 \text { метою забезпечення розширеного відтворення та задоволення } \\
\text { соціальних потреб суспільства. }\end{array}$ \\
\hline $\begin{array}{c}\text { О.М. Ніколаєва, } \\
\text { А.С.Маглапе-рідзе [11] }\end{array}$ & 2013 & $\begin{array}{l}\text { Місцевий бюджет як невід'ємний елемент бюджетної системи країни окреслює економічні } \\
\text { відносини між територіальною громадою, суб'єктами господарювання та фізичними особами, } \\
\text { спрямовані на формування фонду грошових коштів та фінансування місцевих і громадських } \\
\text { потреб, підвищення соціально-економічного розвитку територій та поліпшення добробуту } \\
\text { територіальної громади. }\end{array}$ \\
\hline
\end{tabular}

Джерело: складено автором

Зважаючи на те, що в Україні, як і інших і унітарних, і федеративних країнах місцеві бюджети включають цілу систему взаємопов'язаних фондів, доцільно акцентувати увагу на структуру бюджетної системи та місце в ній саме місцевих бюджетів (рис. 2).

Структура бюджетної системи України станом на 1

Вісник Сумського національного аграрного університету 


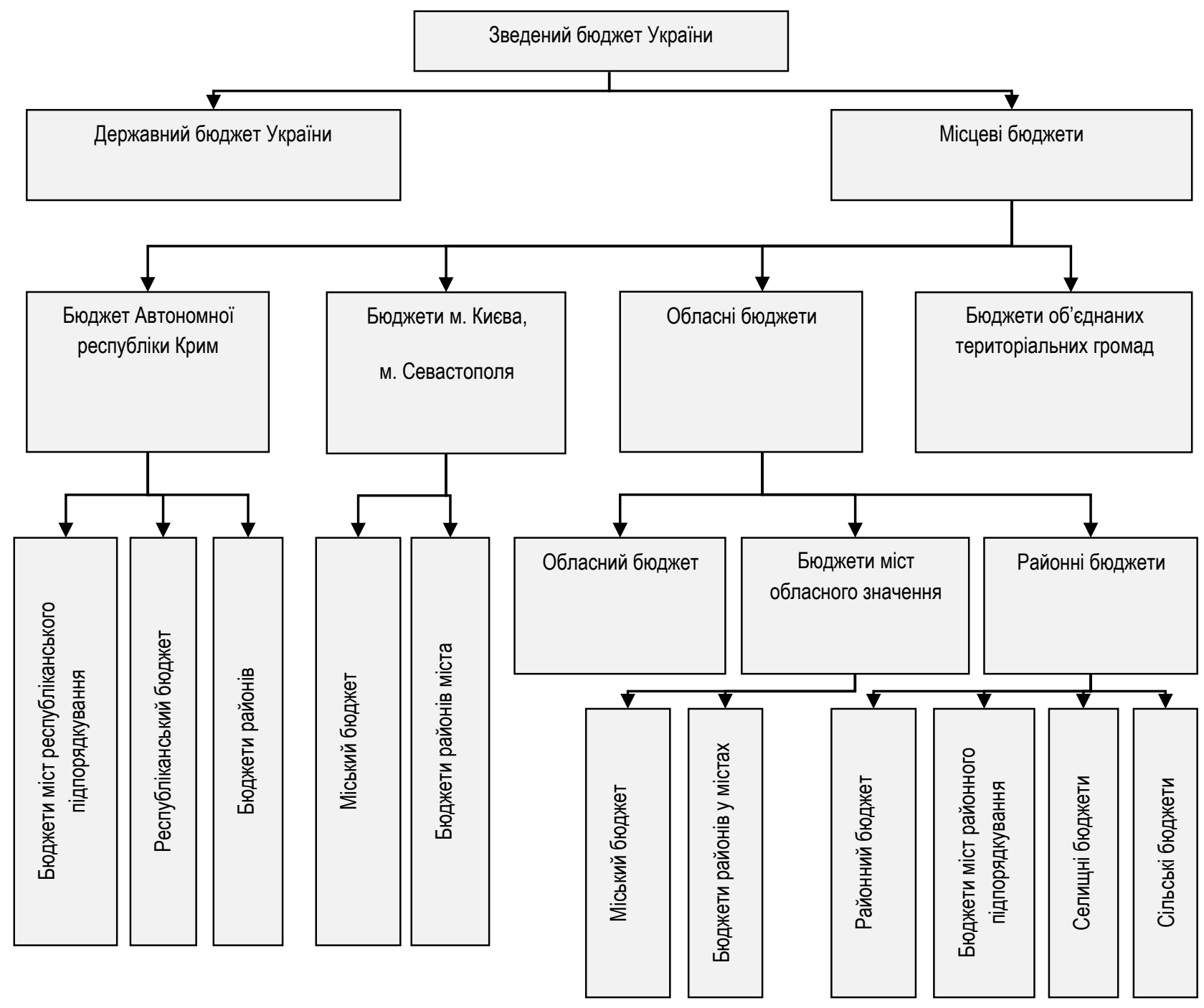

Джерело: розробка автора

Слід акцентувати, що в умовах адміністративнофінансової децентралізації питання ефективного формування місцевого бюджету та його наповнення більшою мірою передане на рівень органів місцевого самоврядування [2]. Перші кроки в цьому напрямі в Україні було зроблено у 2014 році з прийняттям низки важливих законодавчих та нормативно-правових актів, а саме:

- Стратегї̈ сталого розвитку «Україна - 2020», схваленої указом Президента України від 12 січня 2015 року № 5/2015;

- Концепції рефрормування місцевого самоврядування та територіальної організації влади в Україні, затвердженого розпорядженням Кабінету Міністрів України від 1 квітня 2014 р. № 333-р;

- Закону України «Про внесення змін до Бюджетного кодексу України» (щодо реформи міжбюджетних відносин) від 28.12.2014 № 79-VIII;

- Закону України «Про добровільне об'єднання територіальних громад» від 5 лютого 2015 року № 157-VIII [Помилка! Джерело посилання не знайдено.];
- Методики формування спроможних територіальних громад.

В результаті процес формування та виконання місцевих бюджетів зазнав змін у таких напрямах:

1) розпочато реформу місцевого самоврядування та територіальної організації влади;

2) запущено процес формування достатніх фінансово-організаційних умов розвитку територіальних громад;

3) дозволене самостійне формування місцевих бюджетів незалежно від термінів прийняття державного бюджету;

4) запровадження систему вирівнювання податкоспроможності територій;

5) реформовано існуючі податки і збори.

Висновки. Очікуваним результатом зазначених змін $€$ формування спроможних територіальних громад, здатних ефективно здійснювати місцеве самоврядування, забезпечити розширення їх економічного потенціалу, ефективне виконання покладених функцій та укріплення демократії і формування громадянського суспільства на місцевому рівні. В

Вісник Сумського національного аграрного університету 
результаті реформування територіальна громада стає «господарем» на своїй території, що вимагає наявності відповідних фрінансових ресурсів для виконання повноважень, а це передбачає забезпечення ефрективного акумулювання коштів до місцевих бюджетів.

\section{Список використаної літератури:}

1. Пелехатий А.О. Бюджетна політика у забезпеченні розвитку територій: концептуальні домінанти та напрями модернізації. Львів: Львівський національний університет імені Івана Франка, 2019. 386 с.

2. Пелехатий А.О. Інституційно-правове забезпечення формування та реалізації бюджетної політики розвитку територій України. Ж-л «Світ фінансів», №1 (62), 2020 р., с. 140-151

3. Гапонюк М.А., Яцюта В.П., Буряченко А.Є., Славкова А.А. Місцеві фінанси : навч.-метод. посібник К.: КНЕУ, 2002. $184 \mathrm{c}$.

4. Кравченко В.І. Місцеві фінанси України: Навчальний посібник. К.: Знання, 1999. 487 с.

5. Опарін В.М., Федосов В. М., Юхименко П. І. Публічні фінанси: ґенеза, теоретичні колізії та практична концептуалізація. Фінанси України. 2017. № 2. С. 110-128.

6. Василик О.Д. Теорія фінансів: підручник. К.: НІОС, 2000. С. 181.

7. Кириленко О. П. Місцеві бюджети України (історія, теорія, практика). К.: НІОС, 2000. С. 322.

8. Коломієць І. Ф., Пелехатий А. О. Теоретико-практичні аспекти формування об'єднаних територіальних громад в Україні. Економіка України. Київ. 2017, №4 (665), С. 46-55.

9. Матвєєва О.Ю. Використання економічно орієнтованого підходу до визначення поняття «місцеві бюджети» як основи фінансового забезпечення місцевого самоврядування. Державне управління та місцеве самоврядування. 2010. Вип. 2. URL: http://www.dridu.dp.ua/vidavictvo/2010/2010_02\%285\%29/10moyzms.pdf

10. Власюк Н.І. Оцінювання фіскальної ефективності місцевого оподаткування. Науковий вісник НЛтУ України. 2016. Вип. 26.6. С. 68-73.

11. Ніколаєва О.М., Маглаперідзе А. С. Місцевіфінанси: навч. пос. К.: Центр учбової літератури, 2013. 354 с.

12. Пелехатий А.О. Бюджетна політика розвитку територій: методологія дослідження. Ж-л «Бізнес інформ», 2020, №3, c. 476-484

\section{References:}

1. Pelekhatyi A.O. (2019). Biudzhetna polityka u zabezpechenni rozvytku terytorii: kontseptualni dominanty ta napriamy modernizatsii [Budget policy in ensuring the development of territories: conceptual dominants and directions of modernization]. Lviv: Lvivskyi natsionalnyi universytet imeni Ivana Franka, 386.

2. Pelekhatyi A.O. (2020). Instytutsiino-pravove zabezpechennia formuvannia ta realizatsii biudzhetnoi polityky rozvytku terytorii Ukrainy [Institutional and legal support for the formation and implementation of budget policy for the development of the territories of Ukraine]. Svit finansiv- World of Finance, 62 (1), 140-151.

3. Haponiuk M.A., Yatsiuta V.P., Buriachenko A.le., Slavkova A.A. (2002). Mistsevi finansy [Local finance]. Kyiw: KNEU, 184.

4. Kravchenko V.I. (1999). Mistsevi finansy Ukrainy [Local Finance of Ukraine]. Kyiw: Znannia, 487.

5. Oparin V.M., Fedosov V. M., Yukhymenko P. I. (2017). Publichni finansy: geneza, teoretychni kolizii ta praktychna kontseptualizatsiia [Public finances: genesis, theoretical collisions and practical conceptualization]. Finansy Ukrainy - Finance of Ukraine. 2110-128.

6. Vasylyk O.D. (2000). Teoriia finansiv [Theory of finance]. Kyiw: NIOS, 181.

7. Kyrylenko O. P. (2000). Mistsevi biudzhety Ukrainy (istoriia, teoriia, praktyka) [Local budgets of Ukraine (history, theory, practice)]. Kyiw: NIOS, 322.

8. Kolomiiets I. F., Pelekhatyi A. O. (2017). Teoretyko-praktychni aspekty formuvannia obiednanykh terytorialnykh hromad v Ukraini [Theoretical and practical aspects of the formation of united territorial communities in Ukraine]. Ekonomika Ukrainy - Economy of Ukraine. Kyiv. 4 (665), 46-55.

9. Matvieieva O. Iu. (2010). Vykorystannia ekonomichno oriientovanoho pidkhodu do vyznachennia poniattia «mistsevi biudzhety» yak osnovy finansovoho zabezpechennia mistsevoho samovriaduvannia. Derzhavne upravlinnia ta mistseve samovriaduvannia - Public administration and local self-government. Vol. $2 . \quad$ URL: http://www.dridu.dp.ua/vidavictvo/2010/2010_02\%285\%29/10moyzms.pdf

10. Vlasiuk N.I. (2016). Otsiniuvannia fiskalnoi efektyvnosti mistsevoho opodatkuvannia [Assessing the fiscal efficiency of local taxation]. Naukovyi visnyk NLTU Ukrainy [Scientific Bulletin of NLTU of Ukraine]. 26.6, 68-73.

11. Nikolaieva O.M., Mahlaperidze A. S. (2013). Mistsevi finansy [Local finance]. Kyiw: Tsentr uchbovoi literatury, 354.

12. Pelekhatyi A.O. (2020). Biudzhetna polityka rozvytku terytorii: metodolohiia doslidzhennia [Budget policy of territorial development: research methodology]. Biznes inform - Business Inform, 3, 476-484.

Plukar Lyubov Andriyivna, PhD, Private higher educational institution «European University» (Lviv, Ukraine)

Local budgets in conditions of decentralization: theoretical aspects

The periodization of the development of the system of local budgets in the conditions of independence of Ukraine is considered, namely 4 periods: 1990-2000 2001-2009, 2010-2013, 2014 and to date, the basic regulations which were accepted in this period and had the greatest influence on development of the budget system, as well as the main changes that have occurred during this period. The main legislative acts from 2014 were: Sustainable Development Strategy "Ukraine - 2020", the Concept of reforming local self- 
government and territorial organization of power in Ukraine, the Law of Ukraine "On Amendments to the Budget Code of Ukraine", the Law of Ukraine "On Voluntary Association of Territorial Communities" „And Methodology of formation of capable territorial communities. The approaches of Ukrainian scientists to the interpretation of the concept of "local budgets" are studied, namely: Khodorovych I., Kravchenko V., Oparin V., Vasylyk O., Kyrylenko O., Gaponyuk M., Yatsyuta V., Sazonets I., Hrynko T., Prydatko G., Bechko P., Rolinsky O ., Matveeva O., Vlasyuk N., Medinska T., Melnyk M., Nikolaeva O., Maglaperidze A.. The structure of the budget system and the place of local budgets in it are considered. The normative legal acts that had an impact on the formation of budget and tax decentralization have been identified. The main changes in the process of formation and implementation of local budgets in the period of decentralization of budget resources and expenditure powers of local governments, namely: reform of local government and territorial organization of government; the process of formation of sufficient financial and organizational conditions for the development of territorial communities has been launched; independent formation of local budgets is allowed regardless of the terms of adoption of the state budget; introduction of a system of equalization of tax capacity of territories; existing taxes and fees have been reformed. The results of changes in fiscal policy are the formation of capable territorial communities capable of effectively exercising local selfgovernment, ensuring the expansion of their economic potential, effective implementation of assigned functions and strengthening democracy and the formation of civil society at the local level.

Key words: local budgets, local self-government, administrative-territorial reform, decentralization.

Дата надходження до редакції: 20.11.2019 р. 